\title{
Analysis of Psychometric Properties of the Quality and Satisfaction Questionnaire Focused on Sustainability in Higher Education
}

\author{
María del Carmen Olmos-Gómez ${ }^{1, * \mathbb{C}}$, Mónica Luque-Suárez ${ }^{2, *}$, Concetta Ferrara ${ }^{3}$ \\ and Jesús Manuel Cuevas-Rincón ${ }^{1}$ \\ 1 Department of Research Methods and Diagnosis in Education, Faculty of Education and Sport Science, \\ University of Granada, 52005 Melilla, Spain; jcuevas@ugr.es \\ 2 Department of Sociology, Faculty of Education and Sport Science, University of Granada, 52005 Melilla, Spain \\ 3 Associazione Culturale Italiana Per La Formazione, A.C.I.F. University of Naples, Via Salvatore \\ Gambardella, 19, 80145 Napoli NA, Italy; concetta.ferrara@istruzione.it \\ * Correspondence: mcolmos@ugr.es (M.d.C.O.-G.); mlsuarez@ugr.es (M.L.-S.)
}

Received: 10 September 2020; Accepted: 30 September 2020; Published: 8 October 2020

check for updates

\begin{abstract}
The aim of this research was to develop and validate a questionnaire to assess the quality of education, from a sustainability perspective, in higher education institutions of Naples (Italy), and determine whether differences exist between the groups (families, teachers and, students) with respect to their level of satisfaction concerning that quality, since it is important that education policies promote that assessment from an economic, social, environmental, and organisational dimension. The questionnaire was validated using a quantitative, quasi experimental, cross sectional method. A multivariate analysis of variance (MANOVA) was conducted on a sample of $n=1091$ subjects to study the differences between the groups and their level of satisfaction. The results show a good reliability and validity. In this MANOVA, significant differences and large effect sizes were found. Families and teachers consider that quality management in higher education is adequate. The three groups are very satisfied with teaching management, and the teachers' group has the higher level of satisfaction with teaching planning. It is concluded that this validated questionnaire provides information on the opinions about the quality of education from a sustainability perspective and that the self-assessment of those responsible for teaching is essential to achieve continuous improvement.
\end{abstract}

Keywords: quality; multivariate analysis; satisfaction; higher education; sustainability

\section{Introduction}

Quality, nowadays, is generally regarded as a somewhat hollow term that requires a definition consistent with other concepts such as continuous improvement, excellence in performance, and user satisfaction, among others [1], with the latter specifically being one of the quality indicators to which the $21^{\text {st }}$ century society is committed in different fields [2], as well as curricular sustainability, with a view to addressing social, cultural, economic, and environmental problems from a sustainable approach, in all aspects of education and learning [3]. The existing academic field focusing on sustainability studies long-term problems with nonlinear behaviours related to the economic, social, and environmental spheres, locally or globally, which imply a potential damage [4]. In this sense, higher education becomes a key element to ensure that the learning processes of future citizens incorporate this holistic and critical perspective [5], and thus, as pointed out by [6], it is a challenge that educational institutions must meet, through teacher training, for the construction of sustainable societies.

Within the educational context, according to Llanera [7], the concept of quality implies a continuous improvement process in order to better achieve the general objectives and goals of educational 
institutions, and so achieve the satisfaction of the users who participate in the system. Therefore, quality education provides the means to ensure an integral development of individuals so that they can positively contribute to their community from a sustainable development (SD) perspective [8-13].

Education for Sustainable Development (ESD) is developed on the value of education in addressing and understanding the processes of sociocultural change in order to build a sustainable future [14-17]. This implies guaranteeing one of the objectives of the 2030 Agenda for Sustainable Development, which entails ensuring an inclusive, equitable, and quality education [18], hence, the importance of creating a questionnaire that assesses sustainable educational quality. Authors such as Ledden et al. [19] and Simpson [20] explain that educational model dynamics position students as clients who receive a service, which encompasses the second and third focuses (students and teachers) with the first (service). The higher the quality of the service, the more satisfied the clients are. Satisfaction is a mirror image of service performance and has been used in education as the reference instrument to measure it [21]. Such satisfaction is, therefore, based on clients' expectations and perception of service quality [22-24].

Nevertheless, it can be noted that the quality of education has become a problem in the higher education context $[25,26]$. There are initiatives aimed at analysing and satisfying the needs of families, institutions, teachers, and students in particular [27]. Authors such as [28,29] claim that higher education institutions should analyse the quality of their service in order to achieve their goal, that is, the efficiency and effectiveness necessary to satisfy the clients' needs [30-34]. Other authors, such as Larrosa and García-Fernández [35], concluded that collaborating with families in studies on educational quality is a factor influencing teachers' satisfaction.

There are four dimensions that must be fulfilled in order to provide an education of quality [36,37]: the effectiveness of the teaching/learning process, the efficiency to determine the extent to which the objectives have been met and the resources that has been used in the process, the degree to which the educational process satisfies the needs and expectations of any individual, and thereby helps them behave more sustainably, and lastly, the satisfaction that students experience as a result of overcoming their deficiencies thanks to the guidance of their families and teachers $[38,39]$.

In line with the above, there are authors such as Álvarez, García, and Gil [40] who state that four variables are needed in order to analyse the quality of higher education: profession, vocation of teaching, structural and social conditions, and management of the dilemmas and paradoxes inherent to this environment. However, regardless of the aim of previous research studies, it is necessary to highlight the functional dimension of teachers as a key element of quality in higher education, [41] which is emphasised in our research as a driving force that makes it possible to provide an education designed with SD in mind.

There are internal and external factors that define the quality of any education system. The internal factors are defined as any component affecting the quality of the education given that is directly attributable to the agents responsible for the same: the managements of the teaching staff and the parents. Said quality of education, and the satisfaction with the same, is what the present questionnaire was designed to measure. As such, the questionnaire must comply with the established psychometric requisites of validity and reliability.

Based on the considerations stated above, and as a novelty, this research paper aims to:

(1) Develop and validate an instrument to assess the quality of education from a sustainable perspective in higher education institutions. This is important because no instrument currently exists to examine these parameters. A questionnaire was designed and validated in compliance with the psychometric requirements set for its reliability. In order to confirm these characteristics, a semi-confirmatory factor analysis was performed that helped relate the response patterns with an existing group of factors in the people assessed [42].

(2) Determine whether there are differences between the opinions of the groups (families, teachers, and students) and their level of satisfaction with respect to quality in higher education from a 
sustainable perspective through descriptive statistics and the discrimination index results of their questionnaire, as well as the interaction between them using a multivariate analysis of variance.

\section{Materials and Methods}

\subsection{Methods}

This research used a quantitative methodology, since the aim was to define through a questionnaire the existing know-how of the Quality and Satisfaction focused on Sustainability in Higher Education [43-45]. The questionnaire was tested for its rigour, adaptability to context, validity and reliability, and for its capacity to offer objective data with respect to the quality and level of satisfaction in higher education studied.

Exploratory Factor Analysis was used to test said characteristics (EFA). The methodology consists in an analysis of the weighted factor variances. EFA is made up of the following steps. The Kaiser-Meyer-Olkin (KMO) index is calculated. For this to be acceptable, it must be over 0.5 , the sphericity test ensures that the significance is adequate if the variance table is established in the rotated component matrix to link the validation results to the dimensional structure of the tool evaluated.

Although it is possible that the results obtained by a questionnaire of quality and satisfaction focused on Sustainability in Higher Education may include a certain margin of error, for various reasons, this is reduced when there is rigour in the definition of the psychometric parameters.

This research work used social analytical empirical research of a descriptive nature [46] and was based on quantitative study.

Once the reliability and validity of the questionnaire was established, according to the abovementioned process, the most appropriate statistical procedure was performed. To do this, homoscedasticity was analysed using the Levene test, which a Fisher-Snedecor F (Table 6). The homogeneity of the variance between the populations to which the different groups belong was confirmed, and the normal distribution of the quantitative variable in the groups under comparison was analysed (Kolmogorov-Smirnov test), with a sample size $n$ not less than 30 [47]. Although the distribution was not normal (Table 1), the literature supports that with very large samples, such as this case, the analysis of variance can be used without restriction [48-51]. However, for further verification, the Box's M and Wilks' Lambda tests [52-55] were conducted, resulting in rejection of the null hypothesis $(<0.05)$, which confirms the use of a parametric analysis [56,57]. In order to study the relationships between the variables as proposed in the second of our research objectives, a multilevel analysis was conducted to make several comparisons. The multivariate analysis of variance (MANOVA) was used with levels of several factors with the aim of evaluating the differences between the participating groups (families, teachers, and students) as well as their differences according to satisfaction (with values ranging from strongly disagree to strongly agree).

Table 1. Descriptive results of the Quality and Satisfaction focused on Sustainability in Higher Education questionnaire.

\begin{tabular}{ccccccc}
\hline Item & $\overline{\mathbf{X}}$ & SD & Ri-t & Asymmetry & Kurtosis & Commonalities \\
\hline 1 & 4.15 & 1.118 & 0.791 & -0.973 & 0.873 & 0.790 \\
2 & 3.86 & 1.105 & 0.705 & 1.311 & -2.052 & 0.756 \\
3 & 4.07 & 1.054 & 0.562 & -1.205 & -1.998 & 0.741 \\
4 & 3.98 & 0.960 & 0.653 & -1.217 & -2.722 & 0.733 \\
5 & 4.07 & 0.940 & 0.617 & -0.652 & -1.749 & 0.689 \\
6 & 4.05 & 0.947 & 0.369 & -0.921 & -2.183 & 0.669 \\
7 & 3.94 & 0.803 & 0.733 & 0.625 & -1.826 & 0.656 \\
8 & 3.86 & 0.975 & 0.525 & 0.482 & -1.360 & 0.642 \\
\hline
\end{tabular}


Table 1. Cont.

\begin{tabular}{|c|c|c|c|c|c|c|}
\hline Item & $\bar{x}$ & SD & Ri-t & Asymmetry & Kurtosis & Commonalities \\
\hline 9 & 3.59 & 0.951 & 0.593 & 0.600 & -1.878 & 0.634 \\
\hline 10 & 4.16 & 0.692 & 0.654 & -0.950 & -3.061 & 0.592 \\
\hline 11 & 4.13 & 1.079 & 0.504 & -1.230 & -1.557 & 0.589 \\
\hline 12 & 4.03 & 0.967 & 0.590 & 1.270 & -2.456 & 0.580 \\
\hline 13 & 4.28 & 0.864 & 0.525 & 1.519 & -2.897 & 0.568 \\
\hline 14 & 3.90 & 1.067 & 0.643 & -0.981 & -1.351 & 0.563 \\
\hline 15 & 4.34 & 0.814 & 0.665 & -1.589 & -2.866 & 0.550 \\
\hline 16 & 4.36 & 0.842 & 0.793 & -1.460 & -2.367 & 0.519 \\
\hline 17 & 4.15 & 0.886 & 0.650 & -0.940 & -1.810 & 0.499 \\
\hline 18 & 4.54 & 1.016 & 0.550 & -1.071 & 0.636 & 0.489 \\
\hline 19 & 4.19 & 0.860 & 0.693 & -0.948 & -2.270 & 0.447 \\
\hline 20 & 4.14 & 0.817 & 0.575 & -0.805 & -1.919 & 0.751 \\
\hline 21 & 3.89 & 0.854 & 0.578 & -0.694 & -1.878 & 0.748 \\
\hline 22 & 3.94 & 0.909 & 0.654 & 1.145 & -2.505 & 0.746 \\
\hline 23 & 4.25 & 1.014 & 0.611 & -1.419 & -2.074 & 0.651 \\
\hline 24 & 4.39 & 1.126 & 0.672 & -1.331 & -1.074 & 0.655 \\
\hline 25 & 4.28 & 0.891 & 0.196 & -1.198 & -1.932 & 0.639 \\
\hline 26 & 4.23 & 0.771 & 0.384 & -1.332 & -3.276 & 0.608 \\
\hline 27 & 4.67 & 1.049 & 0.648 & -1.016 & 0.286 & 0.603 \\
\hline 28 & 4.60 & 1.198 & 0.550 & -0.753 & -0.160 & 0.590 \\
\hline 29 & 4.15 & 0.843 & 0.692 & -.840 & -1.883 & 0.583 \\
\hline 30 & 4.07 & 0.853 & 0.575 & -0.778 & -2.497 & 0.564 \\
\hline 31 & 4.15 & 0.985 & 0.577 & -0.887 & -1.863 & 0.546 \\
\hline 32 & 4.23 & 0.905 & 0.575 & -1.643 & -3.405 & 0.533 \\
\hline 33 & 4.12 & 0.809 & 0.566 & -1.095 & -2.240 & 0.531 \\
\hline 34 & 4.00 & 0.805 & 0.228 & -1.005 & -2.046 & 0.530 \\
\hline 35 & 3.75 & 0.940 & 0.654 & -0.793 & -1.707 & 0.470 \\
\hline 36 & 3.54 & 0.803 & 0.611 & 0.722 & -1.201 & 0.779 \\
\hline 37 & 3.78 & 0.822 & 0.643 & -1.181 & -3.554 & 0.718 \\
\hline 38 & 3.94 & 0.805 & 0.665 & -1.204 & -3.830 & 0.693 \\
\hline 39 & 3.77 & 0.924 & 0.798 & -1.217 & -3.219 & 0.685 \\
\hline 40 & 3.76 & 0.973 & 0.654 & -1.251 & -2.650 & 0.674 \\
\hline 41 & 3.59 & 0.919 & 0.588 & -1.440 & -4.030 & 0.612 \\
\hline 42 & 3.31 & 0.925 & 0.453 & 1.471 & -4.029 & 0.510 \\
\hline 43 & 3.37 & 0.752 & 0.655 & 1.622 & -5.966 & 0.731 \\
\hline 44 & 4.42 & 0.730 & 0.766 & -0.990 & -1.384 & 0.677 \\
\hline 45 & 4.32 & 0.710 & 0.705 & -1.783 & -3.861 & 0.594 \\
\hline
\end{tabular}

Note: Mean, standard deviation, corrected item-total correlation, asymmetry and kurtosis, commonalities; $\mathrm{SD}=$ standard deviation. $\mathrm{RI}-\mathrm{t}=$ corrected item-total correlation.

\subsection{Participants}

The sample used for the research was nonprobabilistic (accidental or informal). The sample for this study was made up of 1.091 participants (45.9\% students, $11.2 \%$ teachers, and $42.9 \%$ family members). The samples were taken from 16 higher education institutions in the city of Naples, out of a total of 21.

The questionnaire was administered to those who indicated a willingness to participate. The age of students participating ranged between 17 and 25 years old (mean $=19.84$ years). The age of participating teachers ranged between 35 and 45 years old (mean $=38.5$ years). The age of participants who were relatives of families ranged between 50 and 65 years old (mean $=55.9$ years). As regards gender, the sample of the family group was made up of $62 \%$ females and $38 \%$ males. The group of teachers was made up of $51 \%$ women and $49 \%$ men; and within the students group, $43 \%$ were boys and $57 \%$ girls. The socioeconomic level of the families was $63 \%$ medium, $34 \%$ low, and $3 \%$ high. The average 
level of education of the fathers was 1st grade of Secondary School and Vocational Training and the mothers was 1st grade of Secondary School.

\subsection{Instrument}

Each participant received a modified version of the Quality and Satisfaction Questionnaire [43-45] limited and adapted to the border context of the city of Naples and modified for the variable of groups (students, families, and teachers). To select the initial items to be included in the questionnaire, a group of students $(\mathrm{N}=302)$, a group of teachers $(\mathrm{N}=56)$, and families $(\mathrm{N}=81)$ with largely similar characteristics to that of the sample were asked to indicate all the items they considered to be best suited to the ends of the research. After collecting this information, we proceeded to validate the items using an expert panel analysis. Members of the Department of Educational Research Methods and Analysis in Melilla (University of Granada, Andalusia, Spain), devoted to producing and validating psychometric tools, created a questionnaire to measure the degree of satisfaction with the quality of higher education in the northern area of the city of Naples. The tool design was aligned with the main theoretical guidelines for building tests (the American Association of Educational research, the American Association of Psychology, and the National Council for Educational Evaluation 2014). There were seven experts with an opinion concerning the consistency of the instrument through using Delphi's method [58]. These specialists evaluated the tool referred to as Quality and Satisfaction Questionnaire, the concordance index $(\mathrm{K})$, together with the validity of its content $[58,59]$. The final version of the instrument was developed in the exploratory phase.

To test the understanding and clarity of the items included, the first version of the questionnaire was administered in one State school and state-subsidised institution (State/private).

The subsequent version of the questionnaire had 45 items grouped into five sections. This first part was devoted to socio-demographic information: groups (family, students, and teachers) age, gender, and socioeconomic level of the families and students. For the remaining four sections, a Lickert scale was used. The scores are coded from 1 to 5 (from "I don't agree" to "I always agree").

\subsection{Procedure}

\section{Data Collection Procedure}

Contact was established with various higher education centres in the northern areas of the city of Naples; 21 classes in total formed the cohort with the questionnaire applied to all the related subsets of participants in the educational process. The questionnaire was administered over the months of March and April in 2019 and was approved by the directors of the participating schools who collaborated in the research. An e-mail were sent to the schools establishing the voluntary nature of the study and guaranteeing anonymity. The aims and ends of the study were clearly explained. They were distributed and read together within groups of no more than 30 participants. In this study, the instrument was distributed to a sample of 1091 (duration of 30 to $60 \mathrm{~min}$ ). Later, several experts applied the questionnaire in person and on paper. The study was passed by the ethics committee in the Department of the Cooperation and Social Responsibility at the University of Granada. Additionally, the ethical principles of the Declaration of Helsinki were followed at all times.

\subsection{Data Analysis}

Quantitative data were analysed in accordance with descriptive statistics and internal consistency estimations using SPSS 24.0. And semi-confirmatory factorial analysis was conducted using FACTOR Analysis 9.3.1. [60].

\section{Results}

In Table 1, we show all the chosen response categories by means of sample and their standard deviations, all of them higher than 0.71 as a sign of item discrimination. The corrected item-total 
correlation (ri-t) is positive for all items, with values between 0.196 and 0.798 , indicating that all items contribute to measuring what the questionnaire measures and more in the same direction.

We observed that the results obtained by the respondents in the sample collected for each of the items in Quality and Satisfaction focused on Sustainability in Higher Education questionnaire do not follow a normal distribution (Table 1). This is indicated by the indices of asymmetry, kurtosis, and the Kolmogorov-Smirnov test. All the items express a negative asymmetry, which implies that the professionals tend to point out the high values of the Likert scale, except in the following ten items: $2,7,8,9,12,13,32,36,42$, and 43 . These items show a positive asymmetry, which means that the participants tend to point out the low values of the scale.

The commonalities that make up the scale are over 0.30 [61]. The commonalities establish the degree of explained variance of each of the components. In this case, each of the 45 items is described by its components, and as can be seen, there are no values close to zero with the values oscillating between 0.447 and 0.790 .

Regarding the analysis of kurtosis, the indices are negative except for the following: 1, 27, and 18 . This shows that the scores are more grouped and located above the normal distribution curve.

The consistency or the instrument using Delphi's method [58] was evaluated by the concordance index (K). For this purpose, three rounds of content validity analysis were carried out among the experts. The percentage of agreement in the first round was $\mathrm{K}=76 \%$, in the second round was $\mathrm{K}=81 \%$, and in the third was $\mathrm{K}=91 \%$.

Through the program FACTOR Analysis proposed by Lorenzo-Seva and Ferrando [42], a four factor rotation was conducted, which with the following Bartlett's sphericity test allowed us to see that the significance was adequate $(p=0.000)$ and that we could proceed with the factor analysis. The KMO index was calculated, bearing in mind that for it to be acceptable, the value had to be over 0.5. In this case, the KMO was 0.967 , a coefficient close to one, showing that it was appropriate to continue analysing the validity and reliability of the test. The rotated component matrix table was generated by an orthogonal rotation (varimax). This rotation was chosen because it can be demanded that the rotated axes remain orthogonal, given that the factorial loads coincide with the correlations between the observed variables and the factors. Consequently, the orthogonal factors can be used in direct mode in order to interpret the factors $[62,63]$. The result of this analysis explained by the Kaiser-Guttman criterion yielded 5 components to a total value of $70.757 \%$. We applied the Scree criterion (Figure A1, Appendix A) and yielded 4 factors (Table 2).

Table 2. Factor loading of four dimensions of the model of the Quality and Satisfaction focused on Sustainability in Higher Education questionnaire.

\begin{tabular}{ccccc}
\hline Ítems & F1 & F2 & F3 & F4 \\
\hline I9 & 0.790 & & \\
I3 & 0.756 & & \\
I39 & 0.748 & & \\
I37 & 0.733 & & \\
I38 & 0.689 & & \\
I40 & 0.669 & & \\
I21 & 0.656 & & \\
I7 & 0.642 & & \\
I25 & 0.634 & & \\
I17 & 0.592 & & \\
I20 & 0.589 & & \\
I2 & 0.580 & & \\
I4 & 0.568 & & \\
I10 & 0.563 & & \\
I5 & 0.550 & & \\
I23 & 0.519 & & \\
I8 & 0.499 & & \\
\hline
\end{tabular}


Table 2. Cont.

\begin{tabular}{|c|c|c|c|c|}
\hline Ítems & F1 & F2 & F3 & F4 \\
\hline I41 & 0.489 & & & \\
\hline I19 & 0.447 & & & \\
\hline I46 & & 0.751 & & \\
\hline I33 & & 0.748 & & \\
\hline I 45 & & 0.746 & & \\
\hline I 29 & & 0.651 & & \\
\hline I 44 & & 0.645 & & \\
\hline I15 & & 0.639 & & \\
\hline I30 & & 0.608 & & \\
\hline I12 & & 0.603 & & \\
\hline I13 & & 0.590 & & \\
\hline I34 & & 0.583 & & \\
\hline I32 & & 0.564 & & \\
\hline I35 & & 0.546 & & \\
\hline I26 & & 0.533 & & \\
\hline I11 & & 0.531 & & \\
\hline I31 & & 0.530 & & \\
\hline I36 & & 0.470 & & \\
\hline I 28 & & 0.281 & & \\
\hline I27 & & & 0.718 & \\
\hline I18 & & & 0.693 & \\
\hline I16 & & & 0.685 & \\
\hline I1 & & & 0.674 & \\
\hline I24 & & & 0.612 & \\
\hline I14 & & & 0.510 & \\
\hline I6 & & & & 0.594 \\
\hline $\mathrm{I} 22$ & & & & 0.444 \\
\hline I 43 & & & & 0.662 \\
\hline I 42 & & & & 0.706 \\
\hline Alpha & 0.961 & 0.905 & 0.824 & 0.817 \\
\hline
\end{tabular}

Next, the reliability coefficient of the questionnaire was 0.982 , this reflecting a good fit of the observations to the empirical data. Following suppression of three variables, values of 0.961 for factor 1, 0.905 for factor 2, 0.824 for factor 3, and 0.817 for factor 4, were obtained, respectively. Students and parents were grouped into four factors; Factor 1 related to management of higher education and teaching resources (51.747\% total variance). The items were the following: I9, I3, I39, I37, I38, I40, I21, I16, I7, I25, I17, I20, I2, I4, I5, I23, I8, I19, I41, with this final item collecting information relevant to sustainability (existence of specific areas for protection of sustainability material and resources) and with items 16 (subjects reorient education to address sustainability-included on the syllabus), and 20 describing variables that consider sustainability (sustainability activities as a complement to the overall formative development of the student). Factor 2 related to the coordination of educational activities in higher education (total variance $8.048 \%$ ) with the following items: I33, I10, I45, I29, I44, I15, I30, I12, I13, I34 (classrooms and equipment meet sustainability protocols), with these items was obtained information relevant to sustainability: I32, I35, I26, I11, I31, I36, I28. Factor number 3 related to management of teaching in higher education through knowledge of the topics included in the study program (total variance 6.691\%) with the following items: I27, I18, I1, I24, I14. Factor 4 related to teacher planning and teaching staff in higher education ( $4.261 \%$ total variance) covering the following items: I6, I22, I43, I42.

In Table 3, we can see the component transformation matrix. Through it, we found that $46 \%$ of the total variance can be explained through four factors. Next, the validation of the criteria was done through a multivariate regression, whose values are developed in Table 4, the comparative adjustment 
goodness index (CFI) was 0.87; the root mean square error of approximation (RMSEA) was 0.074, with an interval of $0.053-0.080$ and at $90 \%$ confidence [45].

Table 3. Component transformation matrix.

\begin{tabular}{lcccc}
\hline & Factor 1 & Factor 2 & Factor 3 & Factor 4 \\
\hline Factor 1 & 961 & 905 & 824 & 817 \\
Factor 2 & -0.826 & 0.733 & 0.638 & -0.642 \\
Factor 3 & 0.572 & 0.436 & 0.403 & 0.386 \\
Factor 4 & 0.369 & -0.486 & 0.440 & -0.463 \\
\hline
\end{tabular}

Note: Factor 1 = management of higher education and teaching resources; Factor 2 = coordination of educational activities in higher education; Factor 3 = management of teaching in higher education through knowledge of the topics included in the study program; Factor $4=$ teacher planning and teaching staff in higher education.

Table 4. Adjustment index of the model of the Quality and Satisfaction focused on Sustainability in Higher Education questionnaire.

\begin{tabular}{cccccccccc}
\hline & & \multicolumn{4}{c}{ Absolute Adjustment Index } & \multicolumn{4}{c}{ Increased Adjustment Index } \\
\hline $\begin{array}{c}\text { Model } \\
\text { 4 Facts }\end{array}$ & CMIN & P & LO 90 & HI 90 & RMSEA & PNFI & NFI & CFI & TLI \\
45 items & 832.6 & 0.000 & 0.053 & 0.080 & 0.074 & 0.746 & 0.903 & 0.870 & 0.902 \\
\hline
\end{tabular}

After the pilot run, modifications were made to the initial design, eliminating those items that had been detected as difficult to understand, that is, three items were deleted whose loads of two factors differed by less than 0.100 , indicating a possible lack of understanding of the element and, therefore, the need for its reformulation. Thus, the questionnaire was finally left at 45 items of the 48 original items in the questionnaire that made reference to the social structure of the classroom. The tool worked on basic principles taken from other international models of quality evaluation and satisfaction, such as those of Sweden or Italy, based on educational philosophy and curriculum design with a marked focus on the value of work and the sense of all teaching efforts.

Through the Pearson correlation coefficient, it can be seen that the majority of factors $(80 \%)$ demonstrate a significant correlation, the highest value being that obtained for the association between management of coordination of educational activities in higher education and teacher planning and teaching staff in higher education (Table 5).

Table 5. Correlation of factors of the model of the Quality and Satisfaction focused on Sustainability in Higher Education questionnaire.

\begin{tabular}{ccccc}
\hline & Factor 1 & Factor 2 & Factor 3 & Factor 4 \\
\hline Management of higher education and teaching resources & 1 & & & \\
Coordination of educational activities in higher education. & $0.367^{* *}$ & 1 & & \\
Management of teaching in higher education through & $0.397^{* *}$ & $0.542^{* *}$ & 1 & \\
knowledge of the topics included in the study program & $0.612^{* *}$ & $0.711^{* *}$ & $0.484^{* *}$ & 1 \\
Teacher planning and teaching staff in higher education & 0.61 \\
\hline
\end{tabular}

** Correlation significant at the level of 0.01 (bilateral).

Based on the established internal consistency and factorial validity of the questionnaire, in accordance with the above process, the Levene test for variance homogeneity was performed, confirming the appropriateness of the parametric test [64]. To study the relationships between the variables, a multivariate analysis was performed to make multiple comparisons. Analysis of variance (ANOVA) with multiple factor levels was used to assess the difference between the participating groups and the differences in satisfaction focused on sustainability, based on the factors obtained in factor validity. 
Table 6 demonstrate the ANOVA results in relation to grouping variables and satisfaction, as well as the interaction between them. The effect size was analysed using the eta-square tests.

Table 6. ANOVA and effect size $\left(\eta^{2}\right)$ sums of aggregated scales for Quality and Satisfaction Questionnaire focused on Sustainability, by satisfaction and groups.

\begin{tabular}{|c|c|c|c|c|c|c|c|c|}
\hline \multirow[b]{2}{*}{ Factors } & & \multirow[b]{2}{*}{$\mathbf{M}$} & \multirow[b]{2}{*}{ SD } & \multicolumn{2}{|c|}{ CI (95\%) } & \multirow[b]{2}{*}{$\mathbf{F}$} & \multirow[b]{2}{*}{$p$} & \multirow[b]{2}{*}{$\eta^{2}$} \\
\hline & & & & $\begin{array}{l}\text { Lower } \\
\text { Limit }\end{array}$ & $\begin{array}{l}\text { Higher } \\
\text { Limit }\end{array}$ & & & \\
\hline \multirow{3}{*}{$\begin{array}{l}\text { Management of higher } \\
\text { education and teaching } \\
\text { resources }\end{array}$} & Satisfaction & 4.29 & 0.801 & 3.89 & 4.89 & 0.492 & $<0.001$ & $>0.14$ \\
\hline & Groups & 4.03 & 0.796 & 3.62 & 4.23 & 2.241 & $<0.001$ & $>0.14$ \\
\hline & $\begin{array}{c}\text { Satisfaction } \\
\times \text { Groups }\end{array}$ & 4.01 & 0.874 & 3.72 & 4.28 & 1.285 & $>0.001$ & $>0.14$ \\
\hline \multirow{3}{*}{$\begin{array}{l}\text { Coordination of } \\
\text { educational activities in } \\
\text { higher education }\end{array}$} & Satisfaction & 3.98 & 1.098 & 3.46 & 4.09 & 0.796 & $>0.001$ & $<0.14$ \\
\hline & Groups & 3.89 & 0.915 & 3.64 & 4.02 & 2.231 & $<0.001$ & $<0.14$ \\
\hline & $\begin{array}{c}\text { Satisfaction } \\
\times \text { Groups }\end{array}$ & 3.93 & 0.993 & 3.34 & 4.25 & 1.248 & $>0.001$ & $>0.14$ \\
\hline \multirow{3}{*}{$\begin{array}{l}\text { Management of teaching } \\
\text { in higher education } \\
\text { through knowledge of the } \\
\text { topics included in the } \\
\text { study program }\end{array}$} & Satisfaction & 3.75 & 1.231 & 3.13 & 4.02 & 0.997 & $<0.001$ & $>0.14$ \\
\hline & Groups & 3.72 & 0.978 & 3.42 & 4.07 & 3.231 & $<0.001$ & $>0.14$ \\
\hline & $\begin{array}{c}\text { Satisfaction } \\
\times \text { Groups }\end{array}$ & 3.78 & 1.105 & 3.38 & 4.12 & 2.594 & $>0.001$ & $>0.14$ \\
\hline \multirow{3}{*}{$\begin{array}{l}\text { Teacher planning and } \\
\text { teaching staff in higher } \\
\text { education }\end{array}$} & Satisfaction & 3.95 & 0.995 & 3.29 & 4.15 & 0.978 & $<0.001$ & $>0.14$ \\
\hline & Groups & 3.89 & 0.897 & 3.64 & 4.2 & 3.561 & $>0.001$ & $>0.14$ \\
\hline & $\begin{array}{c}\text { Satisfaction } \\
\times \text { Groups }\end{array}$ & 4.04 & 0.979 & 3.63 & 4.22 & 1.198 & $>0.001$ & $>0.14$ \\
\hline
\end{tabular}

Note: The critical alpha level was adjusted for multiple testing to reduce the type I error $(\alpha)$. Thus, the $\alpha$-value was divided by the number of pair comparisons for each ANOVA.

Initially, multivariate analysis of variance (MANOVA) testing indicated significant differences and large effect sizes for quality to satisfaction, significant differences regarding groups and significant outcomes for the interaction between satisfaction and groups. To identify the effects of covariance, we performed the multivariate test for to analyse the relationship between the different levels of the same variable and between the levels of two different variables simultaneously [65]. The fit of ANOVA results to the data reveals significant associations in relation to the quality focused on sustainability in higher education, determined according to groups and satisfaction. Analysis examining satisfaction in relation to differences in groups in higher education. Significant results were produced in relation to: existence of specific areas for protection of sustainability material and resources $(p=0.000)$ for families groups, subjects reorient education to address sustainability—included on the syllabus $(p=0.000)$ and sustainability activities as a complement to the overall formative development of the student $(p=0.000)$ for teachers groups, and classrooms and equipment meet sustainability protocols $(p=0.000)$ for students groups. Thus, it can be seen that quality focused on sustainability in higher education, when considered in relation to the groups and satisfaction, produced large effects sizes in all cases.

\section{Discussion}

Nowadays, there are questionnaires designed specifically to assess quality satisfaction, but it is worth noting the importance of finding questionnaires which are useful and bring together the existing diversity of parameters used to evaluate quality and sustainability development, while allowing for the total construct's dimensions to be measured validly and reliably. However, none of the standardised tools available on the market focus on higher education, but rather cover a range of ages that do not take into account the social and educational characteristics of said group [66]. 
To guarantee quality, one must look at the learning profiles of each and every one of the students in order to come to one sole concept of quality designed to cover all the needs for learning and development in a given period of time [67], as well as the influence of the family and teachers as indicators to improve quality based on sustainable development [45].

In this research paper, an exploratory analysis of the Quality and Satisfaction focused on Sustainability Questionnaire was carried out using the data obtained from the sample. The KaiserMeyer-Olkin (KMO) index, whose value must be greater than 0.50, was found here. It was 0.967, a coefficient that is very close to 1 , which made it reasonable to proceed to test the validity and reliability of the study. Bartlett's test of sphericity showed an adequate significance $(p=0.000)$, which denoted that the data matrix was suitable for factor analysis. The examination of the principal component extraction method resulted in a suggested number of 5 factors. However, taking into consideration the value of the matrix factors and the content of each question, it was considered that the extraction of 4 factors would be more appropriate, in the sense that the construct was much better represented from a theoretical perspective and more consistent with what the questionnaire was intended to measure. The exploratory factor analysis of principal components also identified a six factor structure that accounted for $70.747 \%$ of the variance, but for reasons of adjustment, as explained above, four factors were used to achieve greater convergence.

The results of MANOVA enabled the statistical study of the influence of the independent groups (with three levels: family, students, and teachers) and the level of satisfaction (with four levels) on the coding measured at individual level. The sample size and the proportion of explained variance (in the ANOVA) [68], with respect to the satisfaction-group interaction variable, led to a result of more than $\left(\eta^{2}>0.14\right)$. This suggests that this proportion of differences can be attributed to the opinion that quality focused on sustainability is adequate and, therefore, in turn, groups are satisfied with the teaching management process. Literature explains that eta-squared tests can indicate low effect $r=10$; medium effect $r=0.30$; or high effect $r=0.50$ [69-71]. Therefore, a value above 0.14 is considered high. This was observed when analysing the results of eta-squared test in relation to satisfaction, which denotes that they are satisfied with the quality management within their higher education institution, and with the groups that also consider that quality is adequate [72-75].

\section{Conclusions}

In order to achieve the improvement and innovation in the quality of higher education, a set of indicators should be developed that promote performance assessment and maximise the effectiveness-efficiency of the management system in which this study is based. Thus, the development of a valid and reliable instrument focused on sustainability makes it possible to gather the opinions of those involved in the management process for continuous improvement. This improvement does not depend only on active management policies, but also on the active incorporation of all those directly involved in higher education (families, teachers, and students) $[45,76]$.

There are many studies that deal with educational quality [26,27], but they do not study quality from the point of view of the three groups analysed here (family, teacher, and students). This research study is a step forward in understanding management by groups and their interaction, showing that the three of them consider that teaching management is essential for an improvement in quality and, therefore, their early involvement can be a great starting point to forge a sustainable future.

As justified by Vilches and Gil [77], sustainability in the curriculum does not imply including sustainability content on the syllabus, but rather involves generic changes in the conception of the educational process. For this reason, it is highly relevant to integrate sustainable educational quality from the planning stage of higher studies and in the different subjects, since most university curricula do not take into consideration the objective of educating for a sustainable society [78], and that does not only depend on individuals' interest, but also on their educational development, both within higher education institutions and their family units. 
Sustainability, understood as an integral part of the higher education management system, must be promoted from higher education institutions, which should serve as useful management models of sustainable practices that can be extended to all fields of society. To do this, it is necessary to perform a constant assessment of the parameters of management, quality, curriculum, and sustainable management for its appropriate development and improvement $[79,80]$.

Although the model for assessing the quality of teachers' teaching practices through student satisfaction surveys has proven to be effective [81,82], this system is not without limitations, a proof of which is found in the variables sex [83] and age [84]. However, future research could focus on the level of education of the families or their socioeconomic level as a discrimination variable, as it would be interesting to perform an in-depth study considering these two variables.

From the results obtained in the questionnaire that has been developed, four factors were established that will help to analyse the level of sustainable educational quality and the level of satisfaction of families, teachers, and students. The first factor is the management of higher education and teaching resources. It is highly important as, even if a student has a cognitive evaluation and a favourable predisposition towards higher studies, a poor tangible quality can lead the individual to dissatisfaction. In relation to this factor, the groups of families and teachers have expressed their satisfaction with the current model. These results are consistent with previous research studies $[85,86]$. The second factor is the coordination of educational activities in higher education, which has been used to evaluate the level of satisfaction with the facilities, the environment among the students favouring educational guidance, and the management of the activities [86-88]. Regarding this factor, the opinions of our respondents require greater involvement from the institutions in order for them to adapt to sustainable development. The third factor describes management of teaching in higher education through knowledge of the topics included in the study program. Gil, Roca, and Camisón [89] highlight features such as the technical dimension, the functional dimension, and the academic and guidance structure, which supports the results obtained in our study that reveal a high level of satisfaction in the three groups assessed. Finally, the fourth factor refers to teacher and staff planning in higher education. Basante, Coronel, and Vinueza [90] establish policies aimed at developing schedules and educational management. In this case, teachers have shown the higher level of satisfaction with the development of the current model.

It can be concluded that the validated questionnaire is a useful tool that enables us to capture the opinions on educational quality, from a sustainable perspective, of all those involved in quality management. Therefore, it is important that those who manage teaching promote the assessment of their management in a systematic way, in order to achieve continuous improvement, and, thus, be able to reach the objective of educational quality set out in the United Nations' 2030 Agenda, with the commitment of all the countries involved in it.

Author Contributions: M.d.C.O.-G., M.L.-S., and C.F., conceptualization. M.d.C.O.-G., methodology and validation, and C.F. analysed the data. M.d.C.O.-G. and M.L.-S., writing-review and editing. M.d.C.O.-G., supervision. All authors contributed to data interpretation of the analysis. M.d.C.O.-G., M.L.-S., and J.M.C.-R. wrote the paper with significant input from M.d.C.O.-G. All authors have read and agreed to the published version of the manuscript.

Funding: This research received external funding by Project HUM-983 (ITACA): “Research through transforming learning and contexts." Principal Researcher: Eva María Olmedo-Moreno.

Conflicts of Interest: The authors declare no conflict of interest. 


\section{Appendix A}

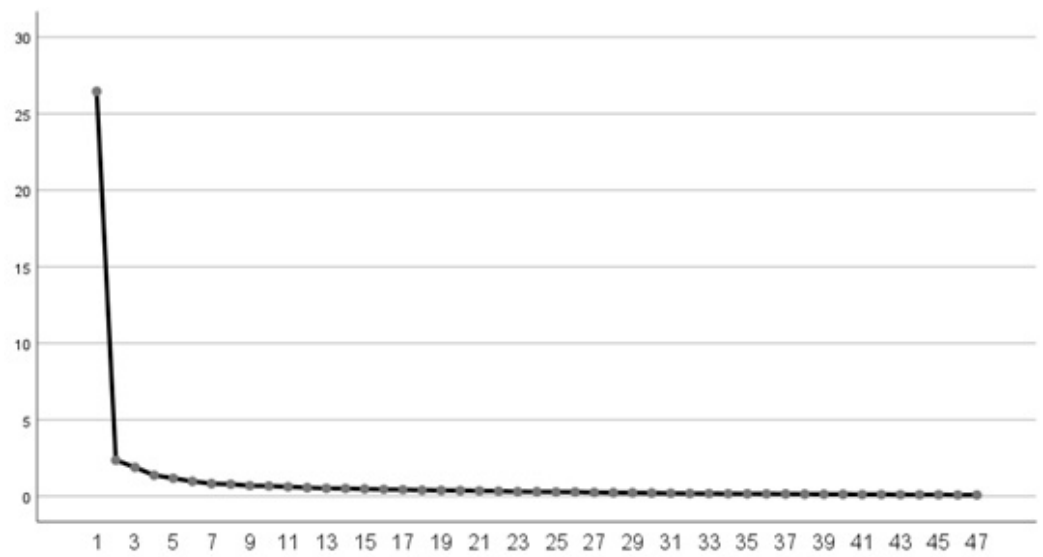

Figure A1. Scree criterion of Quality and Satisfaction Questionnaire focused on Sustainability (Number of Components).

\section{References}

1. Casanova, M. El diseño curricular como factor de calidad educativa. Revi. Iberoam. Calid. Efic. Cambio Educ. 2012, 10, 6-20.

2. Caballero, J. Satisfacción e Insatisfacción de los Directores Escolares; Grupo Editorial Universitario: Granada, Spain, 2001.

3. UNESCO. Education 2030: Incheon Declaration and Framework for Action for the implementation of Sustainable Development Goal 4: Ensure Inclusive and Equitable Quality Education and Promote Lifelong Learning Opportunities for All. París, Francia. 2016. Available online: https://unesdoc.unesco.org/ark: /48223/pf0000245656 (accessed on 16 September 2020).

4. Brundiers, K.; Wiek, A.D.; Redman, C.L. Real-world learning opportunities in sustainability: From classroom into the real world. Intern. J. Sustain. Hig. Educ. 2010, 11, 308-324. [CrossRef]

5. Gonzalo, V.; Sobrino, M.R.; Benítez, L.; Coronado, A. Revisión sistemática sobre competencias en desarrollo sostenible en educación superior. Rev. Iberoam. Educ. 2017, 73, 85-108. [CrossRef]

6. Sáenz-Rico, B.; Benítez, L.; Neira, J.M.; Sobrino, M.R.; D’angelo, E. Perfiles profesionales de futuros maestros para el desarrollo sostenible desde un modelo formativo centrado en el diseño de ambientes de aprendizaje. Foro Educ. 2015, 13, 141-163. [CrossRef]

7. Llarena, M.G.; Villodre, S.; Pontorerio, F.; Cattapan, A. Modelo de Sistema de Gestión de Calidad para la Puesta en Marcha de Cursos No Presenciales: Instrumentos de Seguimiento y Evaluación. Formac. Univ. 2014, 7, 3-16. [CrossRef]

8. Saker, J.; Muñoz, G.; Silvera, A. Calidad humana en el clima organizacional: Influencia en la gestión de empresas responsables. Económicas CUC 2015, 36, 113-125. [CrossRef]

9. United Nations (UN). Post-2015 Development Agenda; United Nations: New York, NY, USA, 2015.

10. Gruber, T.; Fuss, S.; Vossy, R.; Glaser-Zikuda, M. Examining student satisfaction with higher education services. Intern. J. Public Sector Manag. 2010, 23, 105-123. [CrossRef]

11. Al-Rahimy, S.A.S. Students satisfaction with service quality in Jordanian Universities. Interdiscip. J. Contemp. Res. Bus. 2013, 4, 638-644.

12. Petruzzellis, L.; d'Uggento, A.M.; Romanazzi, S. Student satisfaction and quality of service in Italian universities. Manag. Serv. Qual. 2006, 16, 349-364. [CrossRef]

13. Carvalho, S.W.; De Oliveira, M. The role of trust in creating value and student loyalty in relational exchanges between higher education institutions and their students. J. Mark. High. Educ. 2010, 20, 145-165. [CrossRef]

14. Chung, E.; McLarney, C. The classroom as a service encounter: Suggestions for value creation. J. Mark. Res. 2000, 19, 491-504. [CrossRef]

15. UNESCO. Década de la Educación para el Desarrollo Sostenible (2005-2014). Plan de Aplicación Internacional. París. 2006. Available online: https://unesdoc.unesco.org/ark:/48223/pf0000148654_spa (accessed on 24 June 2020). 
16. UNESCO. Educación para los Objetivos de Desarrollo Sostenible: Objetivos de Aprendizaje. In Educación de las Naciones Unidas; Organización Científica y Cultural: París, Francia, 2017; Available online: https: //unesdoc.unesco.org/ark:/48223/pf0000252423?locale=es (accessed on 26 June 2020).

17. UNESCO. Repensar las Politicas Culturales: 10 anos de Promocion de la Diversidad de las Expresiones Culturales Para el Desarrollo: México. DC. 2016. Available online: https://unesdoc.unesco.org/ark: /48223/pf0000245767 (accessed on 26 June 2020).

18. Bokova, I. El Desarrollo Sostenible Comienza por la Educacion. En Unesco, El Desarrollo Sostenible Comienza por la Educacion. UNESCO. 2015. Available online: https://es.unesco.org/news/desarrollosostenible-comienza-educacion (accessed on 25 June 2020).

19. Naciones Unidas. Objetivos de Desarrollo Sostenible. Available online: https://www.un.org/ sustainabledevelopment/es/education/ (accessed on 17 September 2020).

20. Ledden, L.; Kalafatis, S.P.; Mathioudakis, A. The idiosyncratic behaviour of service quality, value, satisfaction, and intention to recommend in higher education: An empirical examination. J. Mark. Manag. 2011, 27, 1232-1260. [CrossRef]

21. Simpson, J.M. Student Perceptions of Quality and Satisfaction in Online Education. Ph.D. Thesis, The University of Alabama, Ann Arbor, MI, USA, 2012.

22. Zineldin, M.; Akdag, H.C.; Vasicheva, V. Assessing quality in higher education: New criteria for evaluating students' satisfaction. Qual. High. Educ. 2011, 17, 231-243. [CrossRef]

23. Ekinci, Y. An Investigation of the Determinants of Customer Satisfaction. Tour. Anal. 2003, 8, $197-203$. Available online: https://www.cabdirect.org/cabdirect/abstract/20043034172 (accessed on 21 July 2020). [CrossRef]

24. Cronin, J.; Taylor, S. Measuring service quality: A re-examination and extension. J. Mark. 1992, 56, 55-88. [CrossRef]

25. Sigala, M. The ASP-Qual model: Measuring ASP service quality in Greece. Manag. Serv. Qual. 2004, 14, 103-114. [CrossRef]

26. Harvey, L.; James, W. Fifteen Years of Quality in Higher Education (Part two). Qual. High. Educ. 2010, 16, 81-113. [CrossRef]

27. Enders, J.; Westerheijden, D.F. Quality Assurance in the European Policy Arena. Policy Soc. 2014, 33, $167-176$. [CrossRef]

28. Romanazzi, S.; Petruzzellis, L.; Lannuzzi, E. “Click \& experience. Just virtually there." The Effect of a Destination Website on Tourist Choice: Evidence from Italy. J. Hosp. Mark. Manag. 2001, 20, 791-813. [CrossRef]

29. Didomenico, E.; Bonnici, J. Assessing Service Quality within the Educational Environment. Education 1996, 116, 353-360. Available online: https://go.gale.com/ps/anonymous?id=GALE\%7CA18434919\&sid= googleScholar\&v=2.1\&it=r\&linkaccess $=$ abs\&issn=00131172\&p=AONE\&sw $=w$ (accessed on 2 August 2020).

30. Awuzie, B.O.; Abuzeinab, A. Modelling Organisational Factors Influencing Sustainable Development Implementation Performance in Higher Education Institutions: An Interpretative Structural Modelling (ISM) Approach. Sustainability 2019, 11, 4312. [CrossRef]

31. Stephens, J.C.; Hernandez, M.E.; Román, M.; Graham, A.C.; Scholz, R.W. Higher Education as a Change Agent for Sustainability in Different Cultures and Contexts. Int. J. Sust. High. Educ. 2008, 9, 317-338. [CrossRef]

32. Farinha, C.; Caeiro, S.; Azeiteiro, U. Sustainability Strategies in Portuguese Higher Education Institutions: Commitments and Practices from Internal Insights. Sustainabiliy 2019, 11, 3227. [CrossRef]

33. Sammalisto, K.; Sundstrom, A.; Holm, T. Implementation of sustainability in universities as perceived by faculty and staff-A model from a Swedish university. J. Clean. Prod. 2015, 106, 45-54. [CrossRef]

34. Too, L.; Bajracharya, B. Sustainable campus: Engaging the community in sustainability. Intern. J. Sust. High. Educ. 2015, 16, 57-71. [CrossRef]

35. Larrosa, F.; García-Fernández, J.M. Percepciones de familias y profesorado de Educación Primaria y secundaria sobre los deberes y derechos docentes y posibilidades de colaboración. Rev. Elec. Investig. Docencia 2014, 11,7-28. Available online: http://www.revistareid.net/revista/n11/REID11art1.pdf (accessed on 30 July 2020).

36. Toranzos, L. Evaluación y calidad. Rev. Iberoam. Educ. 1996, 63-78. [CrossRef] 
37. Galleguillos, P.; Olmedo, E.M. Autoeficacia Académica y Rendimiento Escolar: Un Estudio Metodológico y Correlacional en Escolares. 2017. Available online: https://digibug.ugr.es/handle/10481/45469 (accessed on 13 July 2020).

38. Avendaño-Castro, W.R.; Parada-Trujillo, A.E. Un modelo pedagógico para la reproducción y transformación cultural en las sociedades del conocimiento. Investig. Desarro. 2011, 19, 398-413.

39. Avendaño-Castro, W.R.; Parada-Trujillo, A.E. El currículo en la sociedad del conocimiento. Educ. Educ. 2013, 16, 159-174.

40. Álvarez, V.; García, E.; Gil, J. La calidad de la enseñanza universitaria desde la perspectiva de los profesores mejor valorados por los alumnos. Rev. Educ. 1999, 319, 273-290.

41. Matosas-López, L.; Bernal-Bravo, C.; Romero-Ania, A.; Palomero-Ilardia, I. Quality Control Systems in Higher Education Supported by the Use of Mobile Messaging Services. Sustainability 2019, 11, 6063. [CrossRef]

42. Lorenzo-Seva, U.; Ferrando, P.J. Factor: A computer program to fit the exploratory factor analysis model. Behav. Res. Methods Instrum. Comput. 2006, 38, 88-91. [CrossRef] [PubMed]

43. Correia, S.M.; Miranda, F.J. Duaqual: Calidad percibida por docentes y alumnos en la gestión universitaria. Cuad. Gest. 2012, 12, 107-122. [CrossRef]

44. Arambewela, R.; Hall, J. A comparative analysis of international education satisfaction using servqual. J. Serv. Res. 2006, 6, 141-163.

45. Olmos, M.C.; Luque, M.; Ferrara, C.; Olmedo, E.M. Quality of Higher Education through the Pursuit of Satisfaction with a Focus on Sustainability. Sustainability 2020, 12, 2366. [CrossRef]

46. Howell, D.; William, O.; Turner, S. The analysis of Missing Data. In Handbook Social Science Methodology; Sage: London, UK, 2008; pp. 208-224.

47. Rubio, M.J.; Berlanga, V. Cómo aplicar las pruebas paramétricas bivariadas t de Student y ANOVA en SPSS. REIRE. Revista d'Innovació i Recerca en Educació 2012, 5, 83-100. [CrossRef]

48. López-Roldán, P.; Fachelli, S. Metodología de la Investigación Social Cuantitativa; Universitat Autònoma de Barcelona: Barcelona, Spain, 2015.

49. Gómez-Gómez, M.; Danglot-Banck, C.; Vega-Franco, L. Sinopsis de pruebas estadísticas no paramétricas. Cuándo usarlas. Rev. Mex. Pediatría 2003, 70, 91-99.

50. Berlanga, V.; Rubio, M.J. Clasificación de pruebas no paramétricas. Cómo aplicarlas en SPSS. REIRE. Rev. d'Innovació i Recer. en Educ. 2012, 5, 101-113. [CrossRef]

51. Gardner, R.C.; Escalona García, R. Estadística para Psicología: Usando SPSS para Windows; Universidad Autónoma de Nayarit (UAN), México Biblioteca Central: Nayarit, México, 2003.

52. García, J.A.M.; Caro, L.M. La validez discriminante como criterio de evaluación de escalas.i teoría o estadística? Univ. Psychol. 2009, 8, 27-36.

53. Peña, D. Análisis de Datos Multivariantes; McGraw-Hill: Madrid, Spain, 2013.

54. Vallejo, G.; Ato, M. Robust tests for multivariate factorial designs under heteroscedasticity. Behav. Res. Methods 2012, 44, 471-489. [CrossRef]

55. Cuadras, C.M. Nuevos Métodos de Análisis Multivariante; CMC Editions: Barcelona, Spain, 2007.

56. Gozalo, M.; León-del-Barco, B.; Mendo-Lázaro, S. Good Practices and Learning Strategies of Undergraduate University Students. Int. J. Environ. Res. Public Health 2020, 17, 1849. [CrossRef] [PubMed]

57. Li, S.J.; Wang, Y.L.; Xue, J.; Zhao, N.; Zhu, T.S. The Impact of COVID-19 Epidemic Declaration on Psychological Consequences: A Study on Active Weibo Users. Int. J. Environ. Res. Public Health 2020, 17, 2032. [CrossRef] [PubMed]

58. Escobar, J.; Cuervo, A. Validez de contenido y juicio de expertos: Una aproximación a su utilización. Av. en Med. 2008, 6, 27-36.

59. Elosua, P.; Zumbo, B. Reliability coefficients for ordinal response scales. Psicothema 2008, 20, 896-901.

60. Martínez, A.; Olmos, M.C.; Tomé, M.; Olmedo, E.M. Analysis of Psychometric Properties and Validation of the Personal Learning Environments Questionnaire (PLE) and Social Integration of Unaccompanied Foreign Minors (MENA). Sustainability 2019, 11, 2903. [CrossRef]

61. Comrey, A.L. Manual de Análisis de Factorial; Cátedra: Madrid, Spain, 1985.

62. Pérez, E.R.; Medrano, L.A. Análisis factorial exploratorio: Bases conceptuales y metodológicas. Rev. Argent. de Cienc. del Comport. (RACC) 2010, 2, 58-66.

63. F-Jardon, C.M.; Martos, M.S. Un método para determinar competencias distintivas en pequeñas y medianas empresas. Rev. Adm. da Univ. Fed. de St. Maria 2011, 4, 195-214. 
64. Warner, N.; Letsky, M.; Cowen, M. Cognitive Model of Team Collaboration: Macro-Cognitive Focus. In Proceedings of the 49th Annual Meeting of the Human Factors and Ergonomic Society, Orlando, FL, USA, 26-30 September 2005; Sage CA: Los Angeles, CA, USA, 2005; pp. 269-273.

65. Andréu, J. El análisis multinivel: Una revisión actualizada en el ámbito sociológico. Metodol. Encuestas 2011, 13, 161-176.

66. Falabella, A.; Cortazar, A.; Godoy, F.; Gonzalez, M.P.; Romo, F. Quality Assurance in Early Childhood Education: Lessons from the International Experience. Gest. Polit. Pública 2018, 27, 309-340.

67. Bradbury, A. Understanding Early Years Inequality: Policy. Assessment and Young Children's Identities; Routledge: New York, NY, USA, 2013.

68. Badenes, L.; Frías, D.; Bonilla, A. Un estudio exploratorio sobre el nivel de conocimiento sobre el tamaño del efecto y meta-análisis en psicólogos profesionales españoles. Eur. J. Investig. Health Psychol. Educ. 2018, 7, 111-122. [CrossRef]

69. Howell, D.C. Statistical Methods for Psychology, 6th ed.; Thomson/Wadsworth: Belmont, CA, USA, 2007.

70. Field, A.P. Discovering Statistics Using SPSS: And Sex, Drugs and Rock ' $n$ ' Roll, 3rd ed.; SAGE Publications: Los Angeles, CA, USA, 2009.

71. Cohen, J. Statistical Power Analysis for the Social Sciences; Erlbaum Associates: Hillsdale, NJ, USA, 1988.

72. Coe, R.; Merino, C. Efect Size: A guide for researchers and users. Rev. Psic. 2003, 21, 147-177.

73. Lakens, D. Calculating and reporting effect sizes to facilitate cumulative science: A practical primer for t-tests and ANOVAs. Front. Psychol. 2013, 4, 863. [CrossRef] [PubMed]

74. Richardson, J.T. Eta squared and partial eta squared as measures of effect size in educational research. Educ. Res. Rev. 2011, 6, 135-147. [CrossRef]

75. Olmos-Gómez, M.C. Sex and Careers of University Students in Educational Practices as Factors of Individual Differences in Learning Environment and Psychological Factors during COVID-19. Int. J. Environ. Res. Public Health 2020, 17, 5036. [CrossRef]

76. Litzner, L.I.; Werner, R. La educación para el desarrollo sostenible en la universidad boliviana. Percepciones del profesorado. Teor. Educ. Rev. Interuniv. 2019, 31, 149-173. [CrossRef]

77. Vilches, A.; y Gil, D. (2012, mayo-agosto). La educación para la sostenibilidad en la universidad: El reto de la formación del profesorado. Profr. Rev. de Currículum y Form. del Profr. 2012, 16, 25-43.

78. Díaz-Iso, A.; Eizaguirre, A.; García, A. Extracurricular Activities in Higher Education and the Promotion of Reflective Learning for Sustainability. Sustainability 2019, 11, 4521. [CrossRef]

79. Mulder, K.F.; Segalas, J.; Ferrer-Balas, D. How to educate engineers for/in sustainable development: Ten years of discussion, remaining challenges. Int. J. Sustain. High. Educ. 2012, 13, 211-218. [CrossRef]

80. Thomas, I. Challenges for implementation of education for sustainable development in higher education institutions. In Routledge Handbook of Higher Education for Sustainable Development; Barth, M., Michelsen, G., Thomas, I., Rieckmann, M., Eds.; Routledge: London, UK, 2016; pp. 40-55.

81. Vanacore, A.; Pellegrino, M.S. How Reliable are Students' Evaluations of Teaching (SETs)? A Study to Test Student's Reproducibility and Repeatability. Soc. Indic. Res. Intern. Interdiscip. J. Qual. Life Meas. 2019, 146, 77-89. [CrossRef]

82. Zhao, J.; Gallant, D.J. Student evaluation of instruction in higher education: Exploring issues of validity and reliability. Assess. Eval. High. Educ. 2012, 37, 227-235. [CrossRef]

83. Mitchell, K.M.W.; Martin, J. Gender Bias in Student Evaluations. PS 2018, 51, 648-652. [CrossRef]

84. Wilson, J.H.; Beyer, D.; Monteiro, H. Professor Age Affects Student Ratings: Halo Effect for Younger Teachers. Coll. Teach. 2014, 62, 20-24. [CrossRef]

85. Smith, R.; Ennew, C. Service Quality and Its Impact on Word-of-Mouth Communication in Higher Education; University of Nottingham, Division of Business and Management: Selangor Darul Ehsan, Malaysia, 2001.

86. Alvarado, E.; Ramírez, D.M.; Téllez, E.A. Percepción de la calidad educativa: Caso aplicado a estudiantes de la Universidad Autónoma de Nuevo León y del Instituto Tecnológico de Estudios Superiores de Monterrey. Rev. Educ. Super. 2016, 45, 55-74. [CrossRef]

87. O'Neill, M.A.; Palmer, A. Importance-performance analysis: A useful tool for directing continuous quality improvement in higher education. Qual. Assur. Educ. 2004, 12, 39-52. [CrossRef]

88. González, I. Determinación de los elementos que condicionan la calidad de la universidad: Aplicación práctica de un análisis factorial. RELIEVE Rev. Electrón. Investig. Eval. Educ. 2003, 9, 83-96. [CrossRef] 
89. Gil, M.T.; Roca, V.; Camisón, C. Hacia modelos de calidad de servicio orientados al cliente en las universidades públicas: El caso de la Universitat Jaume I. Investig. Eur. Dir. Econ. Empresa 1999, 5, 69-92.

90. Basantes, R.; Coronel, J.; Vinueza, A. Impacto de la evaluación y acreditación de las carreras profesionales ofertadas por la Universidad Nacional de Chimborazo desde la percepción de los estudiantes. Rev. Cienc. UNEMI 2016, 9, 36-47. [CrossRef] 